\title{
Chemical salivary composition and its relationship with periodontal disease and dental calculus
}

\author{
Anne Alejandra Hernández-Castañeda ${ }^{1}$, Gloria Cristina Aranzazu-Moya ${ }^{1}$, \\ Gerardo Mantilla Mora², Dagmar de Paula Queluz ${ }^{3}$
}

${ }^{1}$ Universidad Santo Tomás, Dentistry School, Department of Oral Medicine, Semiology and Pathology, Bucaramanga, Santander, Colombia

2Universidad Industrial de Santander, School of Medicine, Department of Biochemistry, Bucaramanga, Santander, Colombia

${ }^{3}$ Universidade Estadual de Campinas - UNICAMP, Piracicaba Dental School, Department of Community and Preventive Dentistry, Piracicaba, SP, Brazil

\begin{abstract}
Aim: To determine the relationship between the chemical composition of saliva, periodontal disease and dental calculus. Methods: An observational analytical cross-sectional study was conducted with patients over 55 years of age. Ethical principles of autonomy and risk protection were applied according to the international standards. Sociodemographic and diagnosis variables (presence of dental calculus and periodontal status) were considered to measure salivary concentrations of glucose (by the glucose oxidase/peroxidase method, amylase (by the colorimetric test), urea (by the amount of indophenol), total protein (by the Bradford method) and albumin (by the nephelometric method). Patients chewed a sterile rubber band and $3 \mathrm{~mL}$ of stimulated saliva were collected. The samples were stored at $-5^{\circ} \mathrm{C}$, centrifuged at 2,800 rpm for $10 \mathrm{~min}$, and the supernatant was removed and stored at $-20^{\circ} \mathrm{C}$. Data were presented as frequencies and proportions for qualitative variables and measures of central tendency and dispersion for quantitative variables. Data were analyzed by either analysis of variance or Kruskal Wallis test. A p value $<0.05$ was considered statistically significant. Results: Significant relationships were observed between the concentration of salivary urea and periodontal status $(p=0.03)$ and the presence of dental calculus and urea $(p=0.04)$ was demonstrated. Conclusions: A relationship between the salivary urea concentration and the presence of periodontal disease and dental calculus is suggested.
\end{abstract}

Keywords: dental calculus; urea; periodontal diseases; saliva.

\section{Introduction}

Saliva is an important biological fluid in oral physiology ${ }^{1}$. The reduction of salivary secretion or changes in the properties of the saliva are responsible for a lot of dental and oral problems, such as cavities or periodontal disease, as they

Received for publication: April 07, 2015

Accepted: June 17, 2015

Correspondence to: Anne Alejandra Hernández Castañeda Universidad Santo Tomás Carrera 18 N 9-27 Colombia

Phone: 6800801 ext. 2502 E-mail: anne.usta@hotmail.com remain major diseases, with a direct impact on the quality of life of patients affected by them ${ }^{2-4}$. Among the important components of saliva, there are several enzymes released by stromal, epithelial cells and by bacteria. Salivary amylase involved in digestion of starches also acts as a buffer to protect oral pharyngeal and esophageal mucosae from ingested acids. Saliva protects the teeth against acid by its bicarbonate as buffer and urea ${ }^{5}$. Moreover, drugs like cyclic antidepressants and others could affect the levels of salivary amylase, total proteins and urea $^{6-7}$. 
Analysis of the enzymes in salivary secretion and in the crevicular fluid may help to clarify the pathogenesis and improve the early diagnosis and prognosis of periodontal disease ${ }^{8-10}$. Among salivary composition studies are those concerning lactoferrin, urea, glucose, total proteins, which provide advantages such as elasticity, moisture, buffering effect and repair, thus promoting oral health ${ }^{11-15}$.

With respect to periodontal disease, investigations evaluate the salivary chemical compounds, which contribute in the destruction and/or protection of the periodontal tissues. Concentration of some salivary compounds increases or decreases in patients with periodontal disease because it contains enzymes from periodontal damaged cells, which can be identified in saliva and gingival crevicular fluid ${ }^{16-17}$. Thus, these biomarkers could be used routinely in clinical practice to assess disease progression. The aim of this study was to determine the chemical components in saliva and their relationship with periodontal status and dental calculus in the elderly.

\section{Material and methods}

\section{Population and sample}

An observational analytical cross-sectional study was conducted. The sample consisted of senior patients of the School of Dentistry at Universidad Santo Tomás - Colombia. The sample size was calculated based on a population of 120 individuals, treated at the elderly clinic of Universidad Santo Tomás, between January and December 2013 with 95\% confidence level, 5\% margin of error and a 30\% rate of affected patients. The sample size established for obtaining significant differences was 88 individuals, with an approximate loss of $10 \%$, for a total sample of 98 subjects. People under 55 years old and those who did not wish to participate in the study were not included. In addition, privacy and autonomy was respected, by signing the informed consent and ethical support of the Universidad Santo Tomás, according to national and international standards of human research, \# protocol 18/04072013.

\section{Evaluated variables}

Sociodemographic and socioeconomic data such as age, gender (male and female), origin (rural and urban) and educational level (illiterate, elementary, high school, postsecondary) were collected and the medical condition was registered in a clinical record form. After standardization, clinical assessment was performed to evaluate the periodontal status with a WHO probe according to the criteria established by Bassani et al. (2006) ${ }^{18}$ and Tan (2003) $)^{19}$. For the measurement of dental calculus, the Greene and Vermillion modified method was used, according to criteria established by Aguilar Agulló et al. $(2003)^{20}$. The concentration of amylase, glucose, urea, total proteins and albumin in saliva was evaluated.

\section{Procedures}

\section{Saliva collection:}

The patients were instructed not to drink or eat $120 \mathrm{~min}$ before saliva sample collection and then asked to chew a previously sterilized rubber band. Samples of $3 \mathrm{~mL}$ of saliva were collected, stored in $6 \mathrm{~mL}$ sterile Falcon tubes and kept refrigerated at $5{ }^{\circ} \mathrm{C}$ for $1 \mathrm{~h}^{21}$. The samples were centrifuged at 2,800 $\mathrm{rpm}$ for $10 \mathrm{~min}$ and the supernatant was separated from the substrate and frozen at $-20{ }^{\circ} \mathrm{C}$. Next, the sample was defrosted at room temperature, in groups of twenty samples, and centrifuged at 3,000 rpm. The supernatant was separated again and processed to determine the concentrations of glucose, amylase activity, urea, total protein and albumin.

\section{Chemical analysis \\ Glucose:}

The concentration of glucose was determined by the glucose oxidase / peroxidase $^{22}$ method. The technique is based on the following reaction:

Glucose $+\mathrm{H}_{2} \mathrm{O}+\mathrm{O}_{2} \rightarrow$ gluconic acid $+\mathrm{H}_{2} \mathrm{O}_{2}$ $\mathrm{H}_{2} \mathrm{O}_{2}+4$ aminophenazone-fenol $\rightarrow$ Quinonaimine $+\mathrm{H}_{2} \mathrm{O}$ Considering the following detection limits:

Detection limit: $0.23 \mathrm{mg} / \mathrm{dL}=0.0126 \mathrm{mM} / \mathrm{L}$

Linearity limit: $500 \mathrm{mg} / \mathrm{dL}=27.5 \mathrm{mM} / \mathrm{L}$ measured by spectrophotometer at $505 \mathrm{~nm}$.

\section{Total Proteins:}

The concentration of proteins was determined following the Bradford method (Qian et al., 2014 ${ }^{9}$ ) based on the binding of a dye, Coomassie Blue G-250 to proteins and considering the following detection limits:

Detection Limit: $250 \mu \mathrm{g} / \mathrm{mL}$

Linearity limit: $5 \mathrm{mg} / \mathrm{mL}$

\section{Albumin}

It was determined by the nephelometry method ${ }^{23}$. Using spheres that increase the sensitivity, loaded with antibodies against albumin, it was quantified by colorimetry ${ }^{24}$ in an acid medium with bromocresol green, using a spectrophotometer at $600 \mathrm{~nm}$.

The following detection limits were considered:

Detection limit: $25 / \mu \mathrm{g} / \mathrm{mL}$

Linearity limit: $2.5 \mathrm{mg} / \mathrm{mL}$

\section{Urea}

The urea was quantified by determining the amount of green colored indophenol ${ }^{25}$. It was quantified by spectrophotometer at $600 \mathrm{~nm}$. The technique is based on the following reaction:

$$
\begin{aligned}
& \text { Urea }+\mathrm{H}_{2} \mathrm{O} \stackrel{\mathrm{NH}_{4}+\mathrm{CO}_{2}}{\text { Nitroprusside }} \\
& \mathrm{NH}_{4} \text { salicylate }+\mathrm{NaClO} \rightarrow \quad \text { Indophenol }
\end{aligned}
$$

Considering the following detection limits:

Detection limit: $1.3 \mathrm{mg} / \mathrm{dL}$

Linearity limit: $300 \mathrm{mg} / \mathrm{dL}$

\section{Amylase}

The amylase was quantified by the colorimetric test using 
a 2- chloro - 4 nitrophenil - malatotriosido $\left(\mathrm{CNPG}_{3}\right)$ substrate. By longline action of amylase the $\mathrm{CNPG}_{3}$ degrades releasing 2 -chlor- 4 nitrophenol by increasing the absorbance measured on a spectrophotometer at $405 \mathrm{~nm}^{26}$. The technique is based on the following reaction:

$$
5 \mathrm{CNPG}_{3} \stackrel{\alpha \text { amylase }}{\rightarrow} 3 \mathrm{CNP}+2 \mathrm{CNPG}_{2}+3 \mathrm{G}_{3}+2 \mathrm{G}
$$

All the techniques were verified for accuracy and precision processing a sample of known concentration 10 times for each one, always following the same protocol. With these results, standard deviation, mean, coefficient of variation, absolute error and relative error were calculated.

\section{Normal values of chemicals in saliva:}

As normal parameters, the following control values reported by Carda et al. (2006) ${ }^{27}$ were considered: glucose: <2 mg/dL; amylase: 11.9-304.7 U/mL; urea: 17-41 $\mathrm{mg} / \mathrm{dL}$; albumin: 246-344mg/L; total protein: 1.1-1.8 g/L.

Parameters were considered high when they were above the reference value and low when they were not equal to or lower than reference values.

\section{Processing and analysis of data}

The results of the quantification of quality controls as well as their calculations were entered into Excel and the information was processed in SPSS 21.

Description of the data, frequencies and proportions were calculated for qualitative variables and measures of central tendency and dispersion for quantitative variables. Either an analysis of variance (ANOVA) or a Kruskal Wallis test was conducted, according to the nature and distribution of the variables. A $p<0.05$ was considered statistically significant.

\section{Results}

The sample included 98 subjects, 55.1\% $(\mathrm{n}=54)$ of them were women. The mean age of the subjects was 66.92 years with a standard deviation (SD) of 9.23. The mean age of periodontal status in advanced periodontitis was $70.8 \pm 14.4$ years (Figure 1.A) and according to their procedence; urban individuals had a higher participation with $60 \%$ in gingivitis and $40 \%$ of incipient periodontitis (Figure 1.B). The registered medical condition showed that $4(4.1 \%)$ of the

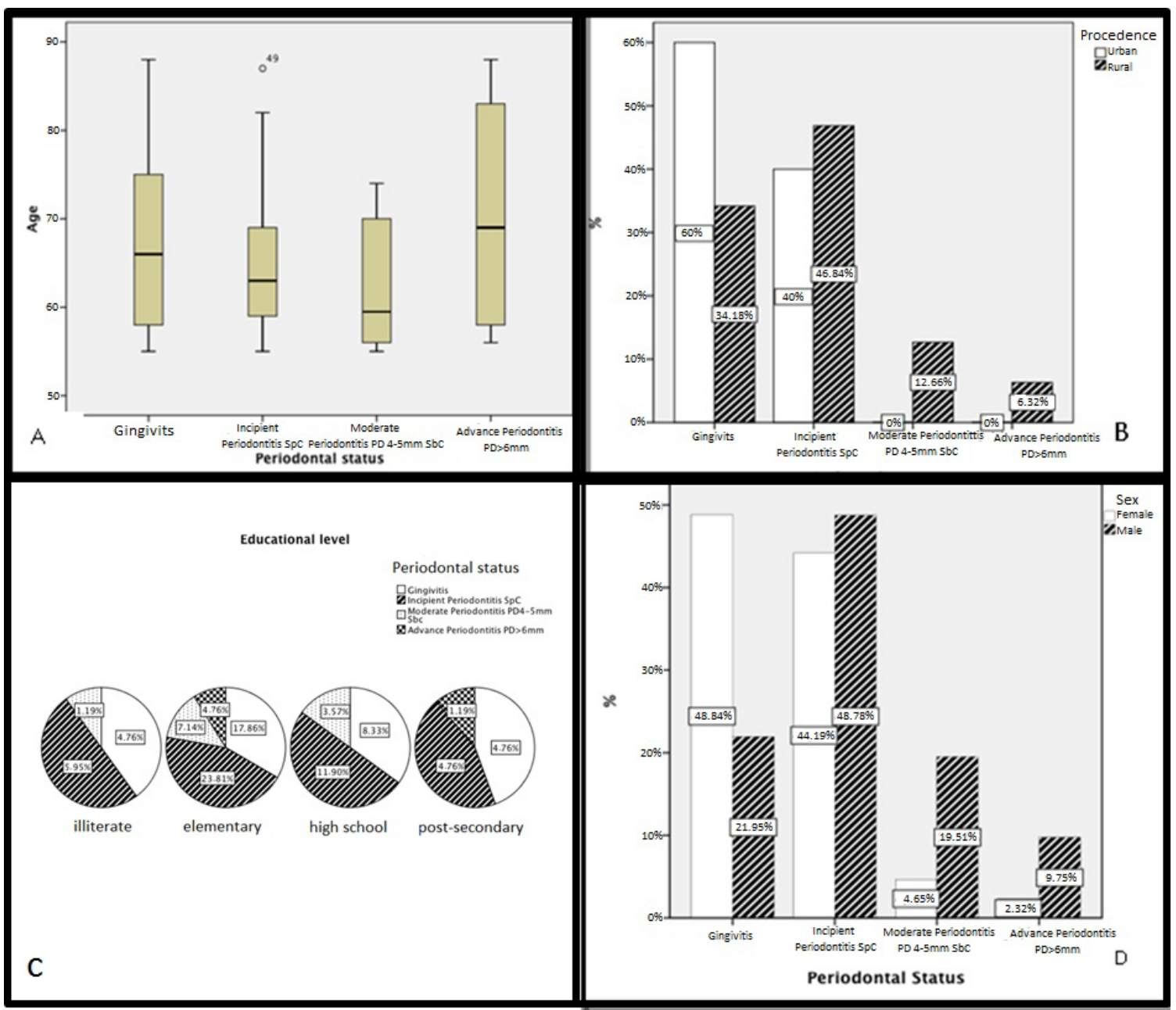

Fig. 1. Sociodemographyc and periodontal status. "Chemical salivary composition and their relationship with periodontal disease and dental calculus" Part A: periodontal status and age; part B: periodontal status and procedence, part C: periodontal status and educational level, part D: periodontal status and Sex. - SpC=Supragingival calculus/ SbC= Subgingival calculus/PD=Probing depth. 
patients had acute kidney disorders and chronic kidney conditions were not present.

Regarding the association between educational level and periodontal status, showed participation of elementary educational level with similar distribution in all cases (Figure 1.C).

Regarding the association between sex and periodontal status, 30 females had periodontal disease, $21(48.8 \%)$ of them presented gingivitis; while 39 males had periodontal disease, $20(48.8 \%)$ of them with incipient periodontitis. There was statistically significant $(p=0.017)$ between sex and periodontal status (Figure 1.D).

Regarding dental calculus, the age had similar distribution (Figure 2.A). According to the precedence, the rural group patients without dental calculus had a higher distribution of cases $(n=32 ; 43.2 \%)$ (Figure 2.B).

Regarding the educational level, elementary education had the highest participation and $15(19.2 \%)$ patients had no dental calculus (Figure 2.C). In the analyses of dental calculus versus sex, higher percentages of dental calculus were found in males (Figure 2.D).

The salivary components were evaluated for total proteins, glucose, albumin, urea and amylase, which were measured quantitatively (by mean and standard deviation) and qualitatively (high, low and normal concentration of chemicals). The average values found globally and according to reference data are shown in Table 1.

Regarding to confidence intervals, glucose and total protein were found in high concentrations in nearly all patients, except for a subject with an average glucose of 2.0 $\mathrm{mg} / \mathrm{dL}$. Low albumin concentrations were found in a large part of the population and the patients presented normal concentrations of urea and amylase (Table 1).

Regarding periodontal status and its relationship with the chemical concentrations of the various salivary components, increased amylase and albumin concentrations was observed in patients with advanced periodontitis, but with no statistically significant differences. On the other hand, a significant association $(p=0.03)$ was found for urea concentration and periodontal disease (Table 2), especially in patients with high concentrations of urea and diagnosed with advanced periodontitis.

Regarding the presence of dental calculus, a higher concentration of amylase was observed in the presence of calculus in more than $2 / 3$ of the tooth surface with no significant difference. Regarding urea, as well as periodontal

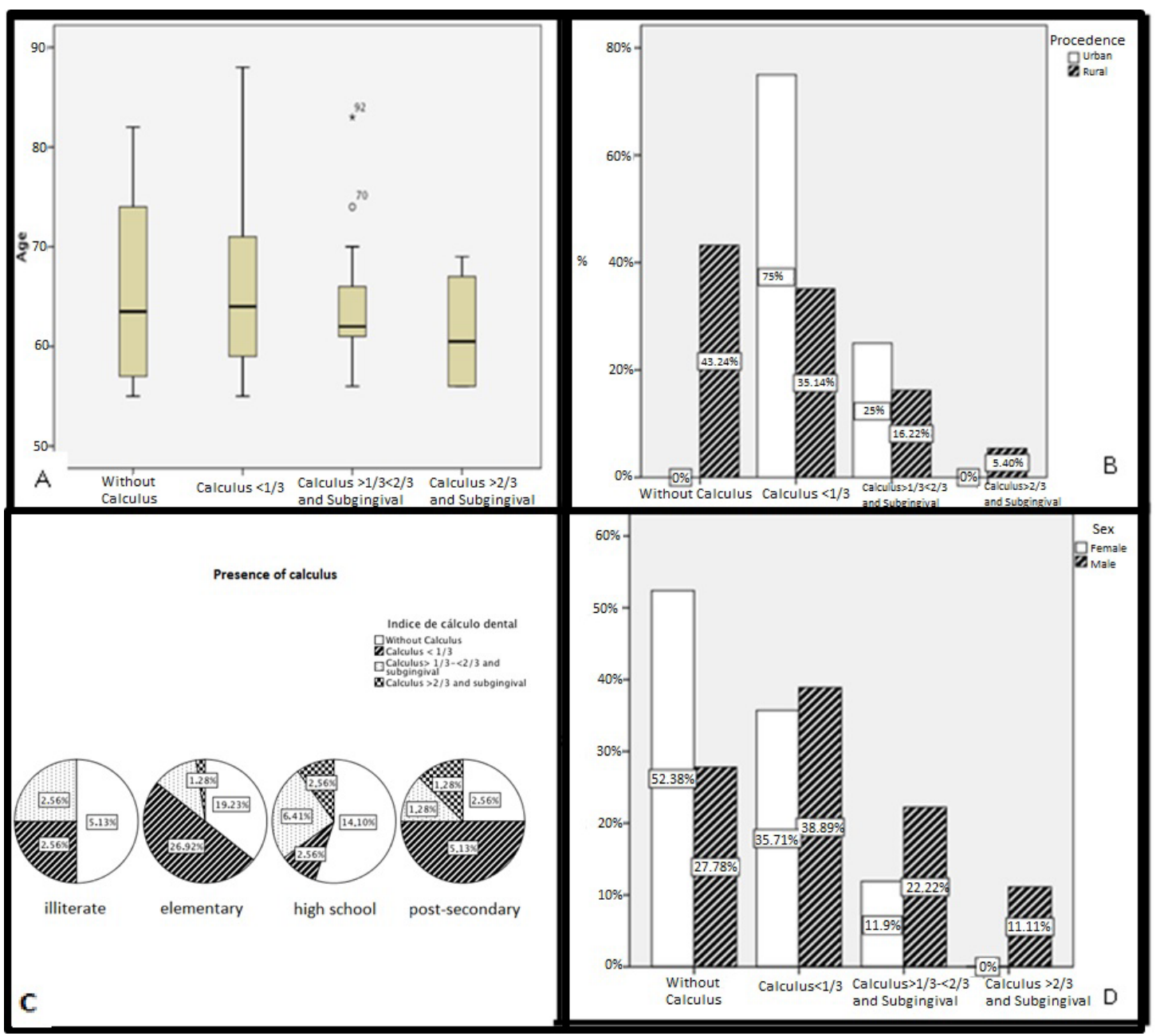

Fig. 2. Sociodemographyc and presence of calculus."Salivary Chemical Characteristics and Its Relationship with Periodontal Disease \& Dental Calculus" Part A: presence of calculus and age; part B: presence of calculus and procedence, part C: presence of calculus and educational level, part D: presence of calculus and Sex. 
Table 1: Concentration of chemicals in saliva.

\begin{tabular}{|c|c|c|c|c|c|c|c|c|}
\hline \multirow{2}{*}{ Salivary Chemistry } & \multicolumn{2}{|c|}{ Global } & \multicolumn{2}{|c|}{ High } & \multicolumn{2}{|c|}{ Low } & \multicolumn{2}{|c|}{ Normal } \\
\hline & IC & $x$ & IC & $\mathrm{X} \pm \mathrm{SD}$ & IC & $\mathrm{X} \pm \mathrm{SD}$ & IC & $\mathrm{X} \pm \mathrm{SD}$ \\
\hline Total protein $(\mathrm{g} / \mathrm{l})$ & $2.1-2.5$ & $2.3 \pm 1.0$ & $2.6-3.1$ & $2.8 \pm 0.9$ & $0.4-1.4$ & $0.9 \pm 0.5$ & $1.35-1.65$ & $1.5 \pm 0.4$ \\
\hline Glucose (mg/dl) & $2.6-2.7$ & $2.7 \pm 0.2$ & $2.6-2.7$ & $2.7 \pm 0.2$ & - - & - - & - - & 2.0 \\
\hline Albumin (mg/l) & $1.9-215.1$ & $206.2 \pm 44.6$ & -—- & -— & $185.2-201.9$ & $193.5 \pm 37.2$ & $243-274.6$ & $258.8 \pm 32.8$ \\
\hline Urea (mg/dl) & $30.3-44.1$ & $37.2 \pm 34.2$ & $62.8-95.0$ & $78.9 \pm 40.7$ & $11.4-13.6$ & $12.5 \pm 2.7$ & $24.9-29.3$ & $27.1 \pm 7.0$ \\
\hline Amylase $(\mathrm{U} / \mathrm{ml})$ & $240.4-395.3$ & $317.9 \pm 386.2$ & $447.8-959.6$ & $703.7 \pm 619.9$ & - - & - - & 171.9-199.6 & $185.7 \pm 59.3$ \\
\hline
\end{tabular}

Confidence interval 95\%. X: Mean $\quad$ SD: Standard deviation.

High: those above the reference value. Low: those not equaled and lower than the reference value. Normal: Glucose: <2 mg / dL; Amylase: $11.9-304.7 \mathrm{U} / \mathrm{mL} ; \mathrm{Urea}$ 17-41mg / dL; Albumin: 246-344mg / L; Total Protein: 1.1-1.8g / L

Table 2: Periodontal status and salivary composition.

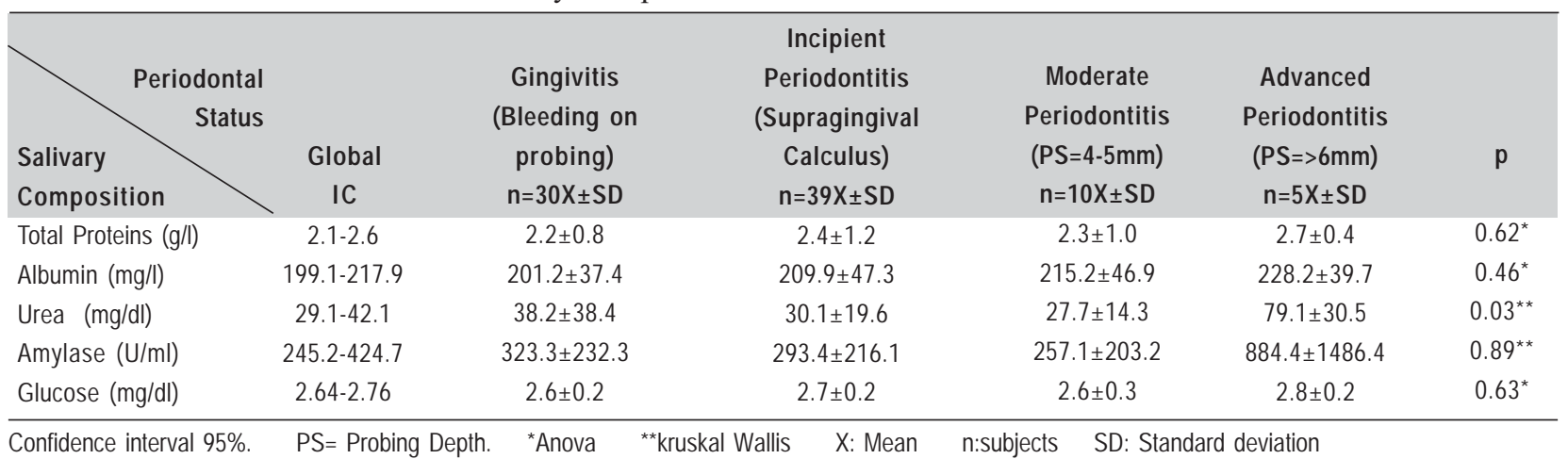

disease, a statistically significant difference $(p=0.04)$ was observed when relating urea and the presence of dental calculus (Table 3), especially when it is observed in more than $2 / 3$ of the tooth structure.

Generally, it could be established that the higher the concentration of urea, the greater the presence of calculus and the severity of periodontal disease.

In order to assess the concentration of salivary urea and kidney disease, the urea average was $28.8 \mathrm{mg} / \mathrm{dL}$ in patients with acute kidney conditions. Compared with patients without it, in whom the urea mean was $37.6 \mathrm{mg} / \mathrm{dL}$ there was no statistically significant difference $(\mathrm{p}=0.46)$.

\section{Discussion}

Protein concentration is considered a biomarker for periodontal disease, since plasma protein leakage occurs as a result of the inflammatory process, which raises the concentration of total proteins in saliva. In this study, higher concentrations of total proteins in the whole population were observed. Shaila et al. $(2013)^{28}$ also found an increase in the concentration of proteins in the presence of gingivitis and periodontitis; however, no differences were found in the group of edentulous patients.

It is known that salivary protein content averages 3,000 $\mathrm{mg} / \mathrm{L}$. Due to these proportions, salivary proteins are involved in numerous biological processes, including cellular support, tissue strain and flexibility, immune response and participation in enzymatic reactions. The functions of these proteins vary according to the type of molecule, so there are some that regulate the maintenance of dental and mucosal integrity, soft tissue repair, regulators of $\mathrm{pH}$ and antimicrobial activity. The salivary concentration of this component may be influenced by factors such as the circadian rhythm, the presence of hormones, psychological disorders, tooth brushing and/or exercise ${ }^{29-30}$.

With respect to albumin, which is considered a marker

Table 3: Dental calculus and salivary composition

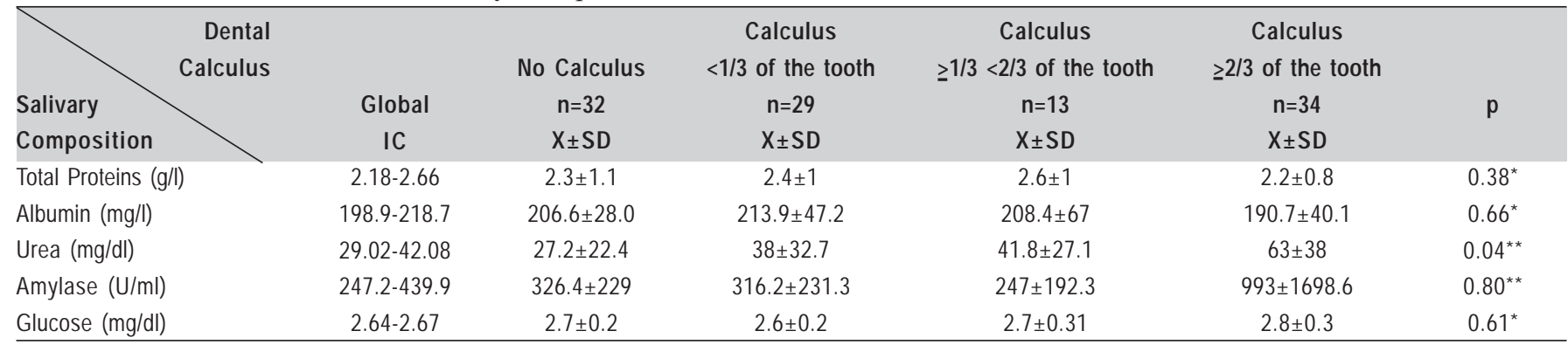

*Anova ${ }^{* *}$ kruskal Wallis $\mathrm{X}$ : Mean $\mathrm{n}$ :subjects $\mathrm{SD}$ : Standard deviation 
of disease, as it originates at a sulcus level. Shaila et al. $(2013)^{28}$ and Cheaib and Lussi $(2013)^{31}$ have suggested that the albumin present in saliva is a consequence of contamination by traces of blood or gingival fluid, considering albumin as an infiltration of serum into the mouth. Its presence has also been reported in patients with periodontitis ${ }^{32}$.

Terrapon et al. (1996) $)^{32}$ in their study, observed an average of over $218.5 \mathrm{mg} / \mathrm{L}$ of albumin. These values are close to the average of albumin in our study, with 206.23 $\mathrm{mg} / \mathrm{L}$. The same authors found a positive correlation between albumin concentration and the severity of periodontitis, increasing the concentration of salivary albumin. However, those authors did not find a significant relationship between pocket depth and the concentration of albumin. In this study, no significant differences in the concentration increase of albumin were observed in the presence of periodontal disease. Nevertheless, an increment in the concentration of albumin was observed as the severity of the disease increased, possibly due to the release of gingival exudate, which increases with the presence of this pathology.

Shaila et al. $(2013)^{28}$ found a significant difference in the concentration increase of albumin and periodontal destruction, concurring with Terrapon et al. $(1996)^{32}$, who mentioned that the saliva in edentulous patients contained five times less albumin than that of dentate patients. They suggested the gingival sulcus as origin of the albumin. Likewise, this study found lower concentrations of albumin in edentulous patients with no statistically significant differences, confirming the data reported by other authors.

Meurman et al. (2002) $)^{33}$ evaluated the salivary albumin, observing higher concentrations of albumin in systemically compromised or weak older adults; what the authors suggest can be used as a reference for comprehensive care of the elderly.

Regarding the presence of dental calculus, BanderasTarabay et al. (1997) $)^{34}$ found that the protein concentration decreases in the presence of dental calculus, contrary to this study, which generally found no protein concentration decrease in the presence of calculus. However, a lower total protein concentration in those with more calculus than others or more than $2 / 3$ of the dental surface without statistically significant differences was observed specifically. This may occur due to the presence of subgingival calculus, preventing the release of plasma proteins as a result of the inflammatory process, decreasing the concentration of total proteins.

Leite et al. (2014) ${ }^{35}$ suggested that there are reduced risks of inflammatory disease in patients who have a polyunsaturated fatty acid (PUFAs) rich diet. PUFAs could be related with an increment of salivary amylase. On the other hand, in this study amylase concentration showed no differences between groups of periodontal disease.

It is important to mention urea as a salivary component since it plays a primary role in the formation of dental calculus. This is why significant values were observed in this study with the presence of dental calculus and urea concentration, possibly due to the alkalization of saliva as a result of high concentrations of urea.

In this regard, Tomás et al. $(2008)^{36}$ found alkaline saliva and high urea concentration, which shows a relationship with the presence of dental calculus. Indirect evidence showed that the metabolism of urea might enhance caries resistance which was seen in patients with chronic renal failure. They are able to produce 10 to 50 -fold greater salivary urea levels. Patients with low levels of urease have low capacity to neutralize glucolite acidification even though high levels of urea are available. This urease could come from bacteria and be a potential caries control strategy ${ }^{37}$.

Other studies have shown the relationship between dental calculus, phosphate and urea concentration in renal patients ${ }^{38-}$ ${ }^{39}$. In this study, the salivary urea concentration was not related to a renal condition because only $4(4.1 \%)$ patients had acute kidney conditions, without significant relationship.

Queiroz et al. (2013) $)^{40}$ found urea reduction ratio of $<65 \%$, in patients with higher frequencies of calculus in pre-transplant patients with chronic kidney disease.

Based on the results, the information regarding salivary composition and its relationship with the different oral alterations has increased, as demonstrated by periodontal disease and the presence of dental calculus. These findings suggest a relationship between dental calculus and variation in the concentration of salivary urea, which makes the study of saliva meaningful as diagnostic and prognostic aids for clinical assessment in dental practice.

\section{Acknowledgements}

The research project had financial support from the Departamento Administrativo de Ciencia, Tecnología e Innovación COLCIENCIAS (Colombia) and the Dentistry School of Universidad Santo Tomás - Colombia.

\section{References}

1. Llena-Puy $C$. The role of saliva in maintaining oral health and as an aid to diagnosis. Med Oral Patol Oral Cir Bucal. 2006; 11: e449-55.

2. Muñoz SL, Narvaez CG. Salivary pH, Buffer Capacity, total proteins and salivary flow in controlled hypertensive patients diuretic users. Int J Odontostomat. 2012; 6: 11-7.

3. Hernández Castañeda AA, Aranzazu Moya GC. Characteristics and physical-chemical properties of saliva: a review. Ustasalud. 2012; 11: 101-11 [spanish].

4. Bretas I, Rocha M, Vieira M, Rodríguez A. Flow Rate and Buffering Capacity of the Saliva as Indicators of the Susceptibility to Caries Disease. Pesq Bras Odontoped Clin Integr. 2008; 8: 289-93 [portuguese].

5. Dawes C, Pedersen AM, Villa A, Ekström J, Proctor GB, Vissink A, et al. The functions of human saliva: A review sponsored by the World Workshop on Oral Medicine VI. Arch Oral Biol. 2015; 60: 863-74.

6. Milton BA, Bhambal A, Nair P. Sialochemical analysis: Windfall to the oral physician (A hospital-based clinical cross-sectional study in depressive disorders). J Int Oral Health. 2014; 6: 82-9.

7. Milton BA, Bhambal A. Sialochemical analysis: a portal for the oral diagnostician. J Clin Diagn Res. 2014; 8: ZC43-8.

8. Cosío Arévalo DJ, Ortega Cambrains A, Vaillard Jiménez E. Determination salivary $\mathrm{pH}$ before, during and after consumption of sweets in children aged 3, 4 and 5 years old. Oral. 2010; 11: 642-5 [spanish]. 
9. Qian X, Dong H, Hu X, Tian H, Guo L, Shen Q, et al. Analysis of the interferences in quantitation of a site-specifically PEGylated exendin-4 analog by the Bradford method. Anal Biochem. 2014; 465: 50-2.

10. Hegde MN, Malhotra A, Hegde ND. Salivary pH and buffering capacity in early and late human immunodeficiency virus infection. Dent Res J (Isfahan). 2013; 10: 772-6.

11. Martins C, Buczynski AK, Maia LC, Siqueira WL, Castro GF. Salivary Proteins as a Biomarker for Dental Caries-A Systematic Review. J Dent. 2013; 41: 2-8.

12. Al Kawas S, Rahim ZH, Ferguson DB. Potential uses of human salivary protein and peptide analysis in the diagnosis of disease. Arch Oral Biol. 2012; $57: 1-9$

13. Acevedo AM, Laguna F. Salivary Mucins and their implications for the rheology of human saliva and saliva substitutes. Acta Odontol Venez. 2009; 47. [spanish]. [cited 2014 Apr 10] Available from: http:// www.scielo.org.ve/pdf/aov/v47n2/art24.pdf.

14. Felizardo KR, Gonçalves RB, Schwarcz WD, Poli-Frederico RC, Maciel $\mathrm{SM}$, Andrade FBD. An evaluation of the expression profiles of salivary proteins lactoferrin and lysozyme and their association with caries experience and activity. Rev Odonto Cienc. 2010; 25: 344-9.

15. Sajewicz E. Effect of saliva viscosity on tribological behavior of tooth enamel. Tribology International. 2009; 42: 327-32.

16. Wolf DL, Lamster IB. Contemporary concepts in the diagnosis of periodontal disease. Dent Clin N Am. 2011; 55: 47-61.

17. Castrillón RLE, Ramos AP, Cabrera SM. Innovative study on lactoferrin in periodontal disease. Rev Odont Mex. 2011; 15: 231-8.

18. Bassani DG, da Silva CM, Oppermann RV. Validity of the Community Periodontal Index of Treatment Needs' (CPITN) for Population Periodontitis Screening. Cad Saude Publica. 2006; 22: 277-83.

19. Tan B. Basic periodontal examination a simple screening tool in general practice. Singapore Dent J. 2003; 25: 55-7.

20. Aguilar Agulló MJ, Cañamas Sanchis MV, Ibáñez Cabanelli P, Gil Loscos F. Importance of the use of index in the periodontal practice by dental hygienist Periodoncia (Barc.) 2003; 13: 233-44. [spanish]

21. Vuletic L, Peros K, Spalj S, Rogic D, Alajbeg L. Time-related Changes in $\mathrm{pH}$, Buffering Capacity and Phosphate and Urea Concentration of stimulated saliva. Oral Health Prev Dent. 2014; 12: 45-53.

22. Abikshyeet $\mathrm{P}$, Ramesh V, Oza N. Glucose estimation in the salivary secretion of diabetes mellitus patients. Diabetes Metab Syndr Obes. 2012; 5: 149-54.

23. Florvall G, Basu S, Helmersson J, Larsson A. Microalbuminuria measured by three different methods, blood pressure and cardiovascular risk factors in elderly Swedish males. Anal Chem Insights. 2008; 3: 69-74.

24. Chen WW, Guo YM, Zheng WS, Xianyu YL, Wnag Z, Jiang XY. Recent progress of colorimetric assays based on gold nanoparticles for biomolecules. Chin J Anal Chem. 2014; 42: 307-14.

25. Shirzaiy M, Heidari F, Dalirsani Z, Dehghan J. Estimation of salivary sodium, potassium, calcium, phosphorus and urea in type II diabetic patients. Diabetes Metab Syndr. 2013 Mar 14. doi: 10.1016/ j.dsx.2013.02.025. [cited 2014 Apr 10]. Available from: http://dx.doi.org/ 10.1016/..dsx.2013.02.025

26. Rohleder N, Nater UM. Determinants of salivary á-amilase in humans and methodological considerations. Psychoneuroendocrinology. 2009; 34: 469-85.

27. Carda C, Mosquera-Lloreda N, Salom L, Gomez de Ferraris ME, Peydro A. Structural and functional salivary disorders in type 2 diabetic patients. Med Oral Patol Oral Cir Bucal. 2006; 11: E309-14.

28. Shaila M, Pai P, Shetty P. Salivary protein concentration, flow rate, buffer capacity and $\mathrm{pH}$ estimation: a comparative study among Young and elderly subjects, both normal and with gingivitis and periodontitis. J Indian Soc Periodont. 2013; 17: 42-6.

29. Gutiérrez Nova P, Olivares Navarrete R, Leyva Huerta ER. Epidermal growth factor and total protein in saliva of smokers and non smokers. Av Odontoestomatol. 2008; 24: 377-83 [spanish].
30. Zárate Daza AN, Leyva Huerta ER, Franco Martínez F. Determination of $\mathrm{pH}$ and total proteins in saliva in patients with and without fixed orthodontic appliances (pilot study). Rev Odontol Mex. 2004; 8: 59-63 [spanish].

31. Cheaib Z, Lussi A. Role of amilase, mucin, IgA and albumin on salivary protein buffering capacity: A pilot study. J Biosci. 2013; 38: 259-65.

32. Terrapon B, Mojon PH, Mensi N, Cimasoni G. Salivary albumin of edentulous patients. Arch Oral Biol.1996; 41: 1183-5.

33. Meurman J, Rantonen P, Pajukoski H, Sulkava R. Salivary albumin and other constituents and their relation to oral and general health in the elderly. Oral Surg Oral Med Oral Pathol Oral Radiol Endod. 2002; 94: 432-8.

34. Banderas-Tarabay JA, González-Begné M, Sánchez-Garduño M, MillánCortéz E, López-Rodriguez A, Vilchis-Velázquez A. Flow and protein concentration in human whole saliva. Salud Publica Mex. 1997; 9433-43 [spanish].

35. Leite MF, Lima HM, Vang SJS, Santos MT, Ohon R. Effect of astaxanthin and fish oil on enzymatic antioxidant. System and a-amylase activity of salivary glands from rats. Braz J Oral Sci. 2014; 13: 58-63.

36. Tomás I, Marinho JS, Limeres J, Santos MJ, Araújo L, Diz P. Changes in salivary composition in patients with renal failure. Arch Oral Biol. 2008 53: 528-32.

37. Reyes E, Martin J, Moncada G, Neira M, Palma P, Gordan W, et al. caries-free subjects have high levels of urease and arginine deiminase activity. J Appl Oral Sci. 2014; 22: 235-40.

38. Martins C, Siqueria WL, Oliveira E, Nicolau J, Primo LG. Dental calculus formation in children and adolescents undergoing hemodialysis. Pediatr Nephrol. 2012; 27: 1961-6.

39. Andrade MR, Salazar SL, de Sá LF, Portela M, Ferreira-Pereira A Soares RM, et al. Role of saliva in the caries experience and calculus formation of Young patients undergoing hemodialysis. Clin Oral Investig. 2015 Mar 20 [In press]. doi: 10.1007/s00784-015-1441-4.

40. Queiroz SM, Amorim AG, Andrade ALD, Gordón-Núñez MA, Freitas $\mathrm{RA}, \mathrm{Galvao} \mathrm{HC}$. Influence of dialysis duration and parathyroid Hormone on the clinical and radiographic oral conditions pre-transplant patients with chronic kidney disease. Braz J Oral Sci. 2013; 12: 125-31. 